\title{
Dose-dependent effects of dietary nitrate on the oxygen cost of moderate-intensity exercise: acute vs. chronic supplementation
}

Lee J. Wylie ${ }^{1}$, Joaquin Ortiz de Zevallos ${ }^{1}$, Taro Isidore ${ }^{1}$, Lara Nyman $^{2}$, Anni Vanhatalo ${ }^{1}$, Stephen J. Bailey ${ }^{1}$ \& Andrew M. Jones ${ }^{1}$

${ }^{1}$ Sport and Health Sciences, College of Life and Environmental Sciences, St. Luke's Campus, University of Exeter, Heavitree, Exeter, EX1 2LU, UK.

${ }^{2}$ Gatorade Sports Science Institute, PepsiCo Global Nutrition R\&D, Barrington, IL, US

Address for correspondence:

Andrew M. Jones, Ph.D.

College of Life and Environmental Sciences

University of Exeter, St. Luke's Campus

Exeter, Devon, EX1 2LU, UK.

E-mail: a.m.jones@exeter.ac.uk

Tel: 01392722886

Fax: 01392264726

Running head: Acute and chronic effects of dietary nitrate

ABSTRACT 
Purpose: To investigate whether chronic supplementation with a low or moderate dose of dietary nitrate $\left(\mathrm{NO}_{3}{ }^{-}\right)$reduces submaximal exercise oxygen uptake $\left(\dot{V}_{\mathrm{O}}\right)$ and to assess whether or not this is dependent on acute $\mathrm{NO}_{3}{ }^{-}$administration prior to exercise. Methods: Following baseline tests, 34 healthy subjects were allocated to receive $3 \mathrm{mmol} \mathrm{NO}_{3}{ }^{-}, 6 \mathrm{mmol} \mathrm{NO}_{3}{ }^{-}$or placebo. Two hours following the first ingestion, and after 7, 28 and 30 days of supplementation, subjects completed two moderate-intensity step exercise tests. On days 28 and 30, subjects in the $\mathrm{NO}_{3}{ }^{-}$groups completed the test $2 \mathrm{~h}$ post consumption of a $\mathrm{NO}_{3}{ }^{-}$dose $(\mathrm{CHR}+\mathrm{ACU})$ and a placebo dose $(\mathrm{CHR})$. Results: Plasma nitrite concentration $\left(\left[\mathrm{NO}_{2}{ }^{-}\right]\right)$was elevated in a dose-dependent manner at 2 h, 7 days and 28-30 days on the CHR+ACU visit. Compared to pre-treatment baseline, $6 \mathrm{mmol} \mathrm{NO}_{3}^{-}$reduced the steady-state $\dot{V} \mathrm{O}_{2}$ during moderate-intensity exercise by $3 \%$ at $2 \mathrm{~h}(P=0.06), 7$ days and at $28-30$ days (both $P<0.05)$ on the $\mathrm{CHR}+\mathrm{ACU}$ visit, but was unaffected by $3 \mathrm{mmol} \mathrm{NO}_{3}{ }^{-}$at all measurement points. On the CHR visit in the $6 \mathrm{mmol}$ group, plasma $\left[\mathrm{NO}_{2}{ }^{-}\right]$had returned to pre-treatment baseline, but the steady-state $\dot{V}_{\mathrm{O} 2}$ remained reduced. Conclusion: $\mathrm{Up}$ to $\sim 4$ weeks supplementation with 6 but not $3 \mathrm{mmol} \mathrm{NO}_{3}{ }^{-}$can reduce submaximal exercise $\dot{V}_{\mathrm{O}}$. A comparable reduction in submaximal exercise $\dot{V}^{\circ}$ following chronic supplementation with $6 \mathrm{mmol} \mathrm{NO}_{3}{ }^{-}$can be achieved both with and without the acute ingestion of $\mathrm{NO}_{3}{ }^{-}$and associated elevation of plasma $\left[\mathrm{NO}_{2}^{-}\right]$.

Key Words: nitrate supplementation; nitrite; nitric oxide; exercise efficiency; $\mathrm{O}_{2}$ uptake

Abbreviations: ANOVA, analysis of variance; ATP, adenosine triphosphate; CHR, effect of chronic nitrate supplementation alone assessed; CHR + ACU, combined effect of chronic and acute nitrate supplementation assessed; GET, gas exchange threshold; $\mathrm{NO}$, nitric oxide; $\mathrm{NO}_{2}{ }^{-}$, 
nitrite; $\mathrm{NO}_{3}{ }^{-}$, nitrate; $\mathrm{O}_{2}$, oxygen; PLA, placebo; Rpm, revolutions per minute; $\dot{V}_{02}$, oxygen uptake; $\dot{V}_{\text {O2peak, }}$ peak oxygen uptake; W, watts; $\Delta$, change.

\section{Introduction}


Dietary nitrate $\left(\mathrm{NO}_{3}{ }^{-}\right)$has been reported to influence several physiological processes via its reduction to nitrite $\left(\mathrm{NO}_{2}^{-}\right)$, and subsequently to the physiological signaling molecule nitric oxide (NO) [1-3]. Indeed, acute ingestion (1-3 h) and chronic supplementation (3-15 days) with dietary $\mathrm{NO}_{3}{ }^{-}$has been found to increase plasma $\mathrm{NO}_{2}{ }^{-}$concentration $\left[\mathrm{NO}_{2}{ }^{-}\right]$, and, in some studies, to reduce the oxygen $\left(\mathrm{O}_{2}\right)$ cost of submaximal exercise [4-6] and improve exercise tolerance [5-7] in healthy, young adults (see [8] for review). However, the influence of different supplementation strategies on the physiological effects of $\mathrm{NO}_{3}{ }^{-}$ingestion is still not fully understood.

Whilst a reduction in the $\mathrm{O}_{2}$ cost of submaximal exercise has been reported 1-3 h post consumption of 5.2-16.8 $\mathrm{mmol} \mathrm{NO}_{3}{ }^{-}$in some studies $[6,9,10]$, reports on the effect of ingesting a lower dose (i.e. $4.2 \mathrm{mmol} \mathrm{NO}_{3}^{-}$or below) are ambiguous [6,11]. It has been suggested that chronic supplementation with $\mathrm{NO}_{3}{ }^{-}$may represent a more effective supplementation strategy $[8,10]$. Indeed, 3-7 days of $\mathrm{NO}_{3}{ }^{-}$supplementation has been reported to improve mitochondrial efficiency [12] and contractile function [13] by altering the expression of mitochondrial [12] and contractile [13] proteins in skeletal muscle. These structural adaptations are likely to be responsible, in part, for the reduction in submaximal $\mathrm{O}_{2}$ uptake $\left(\dot{V} \mathrm{O}_{2}\right)$ after chronic $\mathrm{NO}_{3}{ }^{-}$ supplementation, but would unlikely be manifest within 1-3 h after the ingestion of a single $\mathrm{NO}_{3}{ }^{-}$bolus. Given this potential benefit of a chronic $\mathrm{NO}_{3}{ }^{-}$supplementation period, it may be reasoned that a significant and consistent reduction in submaximal exercise $\dot{V} \mathrm{O}_{2}$ could be achieved with a low dose of $\mathrm{NO}_{3}{ }^{-}$if consumed daily for an extended period of time. However, the effect of chronic supplementation with a low dose of $\mathrm{NO}_{3}{ }^{-}$(i.e. $4.2 \mathrm{mmol}$ or lower) on the $\mathrm{O}_{2}$ cost of submaximal exercise has not yet been investigated. Every nutritional supplement has an associated risk-benefit relationship and financial cost. Determining if a low dose of $\mathrm{NO}_{3}{ }^{-}$ consumed chronically can elicit beneficial physiological effects is therefore important to guide 
supplementation procedures and ensure individuals do not consume more $\mathrm{NO}_{3}^{-}$than is required.

To fully understand the physiological effects of a chronic and acute supplementation strategy, it is important to examine the effects of each strategy independently. In all previous studies assessing the influence of chronic $\mathrm{NO}_{3}{ }^{-}$supplementation on the physiological responses to exercise, subjects have been instructed to consume their final dose of $\mathrm{NO}_{3}^{-} 1-3$ hours prior to final exercise testing, to ensure a significant elevation in plasma $\left[\mathrm{NO}_{2}{ }^{-}\right]$[e.g. 4,5,7,9]. However, this experimental design only allows for the combined chronic and acute effect of $\mathrm{NO}_{3}{ }^{-}$ ingestion to be investigated. Indeed, it is possible that: a) any chronic adaptions to daily $\mathrm{NO}_{3}{ }^{-}$ intake would be detectable in the absence of an acute $\mathrm{NO}_{3}{ }^{-}$dose and thus, no significant elevation in plasma $\left[\mathrm{NO}_{2}{ }^{-}\right]$; and b) any chronic effects of $\mathrm{NO}_{3}^{-}$supplementation may be augmented if an acute $\mathrm{NO}_{3}{ }^{-}$dose is consumed. The adoption of an experimental approach in which the chronic effects of $\mathrm{NO}_{3}{ }^{-}$exposure can be isolated from those of the acute effects is therefore warranted. This will provide important practical information to guide athletes on optimal supplementation strategies before competition after a period of chronic $\mathrm{NO}_{3}{ }^{-}$ supplementation.

The purpose of this study was therefore twofold: firstly, to compare the effects of acute $(2 \mathrm{~h})$, $7 \mathrm{~d}$ and $\sim 30 \mathrm{~d}$ supplementation, with a low dose $(3 \mathrm{mmol})$ and a moderate dose $(6 \mathrm{mmol}$; positive control) of dietary $\mathrm{NO}_{3}{ }^{-}$on the $\mathrm{O}_{2}$ cost of moderate-intensity exercise; and, secondly, to compare the effect of $\sim 30$ day supplementation on the $\mathrm{O}_{2}$ cost of moderate-intensity exercise with and without the acute consumption of $\mathrm{NO}_{3}{ }^{-} 2 \mathrm{~h}$ prior to assessment. To achieve the latter, subjects completed an experimental visit on day 28 and 30 of supplementation: on one visit subjects consumed an acute dose of $\mathrm{NO}_{3}{ }^{-} 2 \mathrm{~h}$ prior to testing $(\mathrm{CHR}+\mathrm{ACU})$; and on the other 
visit, exercise was initiated $24 \mathrm{~h}$ post consumption of the most recent $\mathrm{NO}_{3}{ }^{-}$dose $(\mathrm{CHR})$, allowing plasma $\left[\mathrm{NO}_{2}{ }^{-}\right]$to return to pre- $\mathrm{NO}_{3}{ }^{-}$treatment baseline [6]. It was hypothesized that: a) supplementation with $3 \mathrm{mmol} \mathrm{NO}_{3}{ }^{-}$and $6 \mathrm{mmol} \mathrm{NO}_{3}{ }^{-}$would result in a lower $\mathrm{O}_{2}$ cost of submaximal exercise at $7 \mathrm{~d}$ and 28-30 d on the CHR + ACU visit; and, b) any effects observed with CHR + ACU would still be present, albeit to a lesser extent, with CHR.

\section{METHODS}

\subsection{Subjects}

Thirty-four healthy, recreationally-active subjects ( 19 male, mean $\pm \mathrm{SD}$ age $=21 \pm 3 \mathrm{yr}$, stature $=1.74 \pm 0.09 \mathrm{~m}$, body mass $=73.5 \pm 14.1 \mathrm{~kg}$ ) volunteered to participate, gave written informed consent, and completed this study that was approved by the Institutional Research Ethics Committee. All subjects were nonsmokers and none were taking any nutritional supplements in the four months preceding the start of the study. Throughout the experimentation, subjects were asked to adhere to their normal exercise routine and diet. However, subjects were instructed to avoid foods rich in $\mathrm{NO}_{3}{ }^{-}$(such as green leafy vegetables and beetroot) and asked to record their diet and exercise in the $48 \mathrm{~h}$ preceding the first laboratory visit and to repeat this prior to all subsequent visits. Subjects were instructed to arrive at the laboratory in a rested and fully hydrated state, at least $2 \mathrm{~h}$ postprandial, and to avoid strenuous exercise in the $24 \mathrm{~h}$ preceding each testing session. Each subject was also asked to avoid caffeine and alcohol 6 and $24 \mathrm{~h}$ before each test, respectively. In addition, subjects were asked to abstain from using antibacterial mouthwash and chewing gum for the duration of the study since this inhibits the reduction of $\mathrm{NO}_{3}{ }^{-}$to $\mathrm{NO}_{2}^{-}$in the oral cavity [14]. All laboratory visits were scheduled at the same time of day $( \pm 1 \mathrm{~h})$ for each subject.

\subsection{Pre-treatment tests}


Subjects were required to report to the laboratory on two separate occasions prior to beginning 30 days of supplementation with $3 \mathrm{mmol} \mathrm{NO}_{3}{ }^{-}, 6 \mathrm{mmol} \mathrm{NO}_{3}{ }^{-}$, or placebo (PLA). All exercise tests were performed on an electronically-braked cycle ergometer (Lode Excalibur Sport, Groningen, The Netherlands). During visit 1, subjects completed a ramp incremental exercise test to the limit of tolerance for the determination of peak $\dot{V}_{\mathrm{O} 2}\left(\dot{V}_{\mathrm{O} 2 \text { peak }}\right)$ and gas exchange threshold (GET). The subjects cycled at a constant self-selected pedal rate (80-90 rpm), and this pedal rate, along with saddle and handle bar height configuration, was recorded and reproduced in subsequent tests. Initially, subjects performed 3 min of baseline cycling at $20 \mathrm{~W}$, after which the work rate increased at a rate of $30 \mathrm{~W} \cdot \mathrm{min}^{-1}$ in a linear fashion until the limit of tolerance. The test was terminated when the pedal rate fell by $>10 \mathrm{rpm}$ below the chosen pedal rate, despite strong verbal encouragement. The power output achieved at the point of exhaustion was recorded as the peak power output (PPO). Pulmonary gas exchange was continuously collected breath-by-breath during the incremental tests and averaged over consecutive 10 -s periods. The $\dot{V}_{\text {Oppeak }}$ was calculated as the highest 30 -s mean value attained before the subject's volitional exhaustion. The GET was determined as described previously $[15,16]$. The work rate that would require $80 \%$ of the GET (moderate exercise) was then calculated, with account taken of the mean response time for $\dot{V}_{\mathrm{O} 2}$ during ramp exercise (i.e. two-thirds of the ramp rate was deducted from the work rate at GET; [17]).

During visit 2, subjects completed a series of PLA-controlled, baseline measurements. All subjects were asked to consume a $50 \mathrm{~mL}$ dose of PLA containing negligible $\mathrm{NO}_{3}{ }^{-}$(see description under Supplementation procedures for further details), $2 \mathrm{~h}$ prior to arrival at the laboratory. Upon arrival a venous blood sample was obtained for the measurement of plasma $\left[\mathrm{NO}_{3}{ }^{-}\right]$and $\left[\mathrm{NO}_{2}{ }^{-}\right]$. Subjects then completed two step transitions to moderate-intensity cycling at $80 \%$ GET, with each bout separated by 5 -min of passive recovery. Each step transition was 
preceded by $3-\mathrm{min}$ of baseline cycling at $20 \mathrm{~W}$ and each bout lasted $5 \mathrm{~min}$. Pulmonary $\dot{V}_{\mathrm{O} 2}$ was measured breath-by-breath throughout the test and averaged over 10-s periods. The data from the two moderate-intensity bouts were time aligned and averaged to improve signal-to-noise ratio [18]. The $\mathrm{O}_{2}$ cost of moderate-intensity exercise was then calculated. All measurements made during this visit were used as pre-treatment baseline data.

\subsection{Supplementation procedures}

After these pre-treatment visits, subjects were assigned in a group-matched fashion for moderate-intensity end-exercise $\dot{V} \mathrm{O}_{2}, \mathrm{PPO}$, GET and $\dot{V}_{\text {O2peak }}$, to receive either $\sim 3 \mathrm{mmol} \mathrm{NO}_{3}{ }^{-}$ (administered as $9.75 \mathrm{~g}$ of dry beetroot extract [PepsiCo, USA] diluted in $50 \mathrm{~mL}$ of water), 6 mmol $\mathrm{NO}_{3}{ }^{-}$(administered as $19.5 \mathrm{~g}$ of dry beetroot extract [PepsiCo, USA] diluted in $50 \mathrm{~mL}$

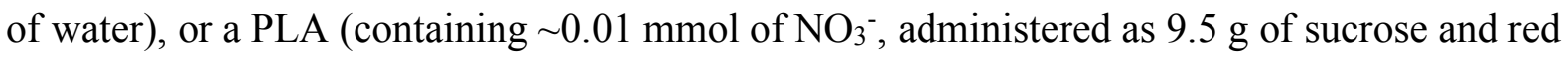
shade coloring [PepsiCo, USA] diluted in $50 \mathrm{~mL}$ of water) per day, for 30 days. Subject characteristics are provided in Table 1.

Subjects reported to the laboratory on days 1, 7, 28 and 30 of supplementation to complete the full experimental protocol from visit 2 (Fig. 1). On supplementation days 1 and 7 , subjects were asked to consume their $1^{\text {st }}$ and $7^{\text {th }}$ dose of supplement, respectively, $2 \mathrm{~h}$ prior to arrival at the laboratory. This pre-test consumption time was selected in order to coincide with the peak plasma $\left[\mathrm{NO}_{2}{ }^{-}\right]$. While we have previously established that peak plasma $\left[\mathrm{NO}_{2}\right]$ is attained $2 \mathrm{~h}$ post beetroot juice consumption [6], it could not be assumed that this time-to-peak is consistent after consumption of other $\mathrm{NO}_{3}$ containing supplements because the kinetics of plasma $\left[\mathrm{NO}_{2}\right]$ may be altered by the form in which the $\mathrm{NO}_{3}$ is administered [19]. We therefore undertook a pilot study which indicated that peak plasma $\left[\mathrm{NO}_{2}\right]$ occurred at $2 \mathrm{~h}$ post consumption of the dry beetroot extract (unpublished observation). On non-experimental days, each subject was 
instructed to consume their allocated supplement at their test time from visit 2 ( $\pm 10 \mathrm{~min})$, such that the subject would consume one dose of supplement every $24 \mathrm{~h}$.

To assess the effect of chronic $\mathrm{NO}_{3}{ }^{-}$supplementation on the $\mathrm{O}_{2}$ cost of submaximal exercise with and without the acute consumption of $\mathrm{NO}_{3}^{-} 2 \mathrm{~h}$ prior to exercise, a randomised counterbalanced design was adopted from day 28 of supplementation for subjects in the $3 \mathrm{mmol}$ and 6 mmol groups (Fig. 1). Two hours prior to arrival on day 28 of supplementation, subjects in the $3 \mathrm{mmol}$ and $6 \mathrm{mmol}$ groups were asked to consume either a PLA beverage [i.e. effect of chronic $\mathrm{NO}_{3}{ }^{-}$supplementation alone $(\mathrm{CHR})$ was assessed] $(3 \mathrm{mmol}: \mathrm{n}=6 ; 6 \mathrm{mmol}: \mathrm{n}=6)$ or their allocated $\mathrm{NO}_{3}{ }^{-}$-rich beverage [i.e. combined effect of chronic and acute $\mathrm{NO}_{3}{ }^{-}$ supplementation $(\mathrm{CHR}+\mathrm{ACU})$ was assessed] $(3 \mathrm{mmol}: \mathrm{n}=5 ; 6 \mathrm{mmol}: \mathrm{n}=6)$. Ten-minutes post completion of the test procedures on day 28, subjects in the $3 \mathrm{mmol}$ and $6 \mathrm{mmol}$ group who consumed PLA prior to the test, consumed a dose of their allocated $\mathrm{NO}_{3}{ }^{-}$-rich beverage, and those that consumed their $\mathrm{NO}_{3}{ }^{-}$-rich beverage consumed a PLA beverage. Two hours prior to arrival at the laboratory on day 30 , subjects consumed the opposite beverage to that consumed prior to their laboratory visit on day 28 [e.g. if PLA was consumed prior to arrival on day 28, then their allocated $\mathrm{NO}_{3}{ }^{-}$-rich beverage was consumed prior to arrival on day 30]. Therefore, all subjects were assessed for the $\mathrm{CHR}+\mathrm{ACU}$ and $\mathrm{CHR}$ effects of $\mathrm{NO}_{3}{ }^{-}$ supplementation. In all cases, subjects in the $3 \mathrm{mmol}$ and $6 \mathrm{mmol}$ groups consumed $3 \mathrm{mmol}$ $\mathrm{NO}_{3}{ }^{-}$or 6 mmol $\mathrm{NO}_{3}{ }^{-}$, respectively, per day. Subjects in the PLA group were instructed to continue their normal supplementation routine and consume one dose of PLA $2 \mathrm{~h}$ prior to arrival at the laboratory on both day 28 and 30 of supplementation.

Subjects in the $3 \mathrm{mmol}$ and $6 \mathrm{mmol}$ groups were deliberately misinformed that the effects of two different $\mathrm{NO}_{3}{ }^{-}$supplements on the physiological responses of exercise would be tested after different supplementation periods. Subjects in the PLA group were informed that the 
effect of a $\mathrm{NO}_{3}{ }^{-}$supplement would be tested over different supplementation periods. All subjects were asked to not comment on the taste or appearance of the supplements to the study investigators. Follow up verbal interviews after completion of the study confirmed that subjects were unaware of the actual research hypothesis.

\subsection{Measurements and data analysis}

During all exercise tests, pulmonary gas exchange and ventilation were measured breath-bybreath, with subjects wearing a nose clip and breathing through a low dead space, lowresistance mouthpiece and impeller turbine assembly (Jaeger Triple V, Hoechberg, Germany). The inspired and expired gas volume and gas concentration signals were continuously sampled at $100 \mathrm{~Hz}$, the latter using paramagnetic $\left(\mathrm{O}_{2}\right)$ and infrared $\left(\mathrm{CO}_{2}\right)$ analyzers (Jaeger Oxycon Pro, Hoechberg, Germany) via a capillary line connected to the mouthpiece. The gas analyzers were calibrated before each test with gases of known concentration, and the turbine volume transducer was calibrated with a 3-liter syringe (Hans Rudolph, Kansas City, MO). Pulmonary gas exchange and ventilation were calculated and displayed breath-by-breath.

The breath-by-breath gas exchange data collected during the two identical, moderate-intensity step tests performed at pre-treatment baseline on visit 2 and on days 1, 7, 28 and 30 of supplementation, were averaged over 10-s periods, and time aligned to the start of exercise and ensemble-averaged. The end-exercise $\dot{V}_{\mathrm{O} 2}$ was defined as the mean value measured over the final $60 \mathrm{~s}$ of exercise.

Venous blood samples were drawn into lithium-heparin vacutainers (7.5 $\mathrm{ml}$ Monovette lithium heparin; Sarstedt, Leicester, UK). Within 1 min of collection, samples were centrifuged at 
$4,000 \mathrm{rpm}$ and $4^{\circ} \mathrm{C}$ for $8 \mathrm{~min}$. Plasma was extracted and immediately frozen at $-80^{\circ} \mathrm{C}$ for later analysis of $\left[\mathrm{NO}_{3}{ }^{-}\right]$and $\left[\mathrm{NO}_{2}{ }^{-}\right]$as previously described [6].

Capillary blood samples were collected from a fingertip into a capillary tube during the $20 \mathrm{~s}$ preceding each step transition in work rate and within the final $20 \mathrm{~s}$ of each moderate-intensity bout. These samples were subsequently stored on ice and analyzed to determine blood [lactate] (YSI 1500, Yellow Springs Instruments, Yellow Springs, OH), within 5 min of collection.

\subsection{Statistical analysis}

A mixed-model ANOVA was used to assess differences in change from pre-treatment baseline, in all variables across treatment (PLA, $3 \mathrm{mmol} \mathrm{NO}_{3}{ }^{-}$and $\left.6 \mathrm{mmol} \mathrm{NO}_{3}{ }^{-}\right)$and time $(2 \mathrm{~h}$ and $7 \mathrm{~d}$, and the CHR $+\mathrm{ACU}$ visit on day 28 or 30 of supplementation). Differences over time within each group were analyzed by a single factor repeated-measures ANOVA. Before these analyses, all data collected on days 28 and 30 of supplementation in the PLA group were averaged together to form one data point at days 28 and 30 of supplementation. The effect of CHR on all variables in $3 \mathrm{mmol}$ and $6 \mathrm{mmol}$ was analyzed separately using a single factor repeated measures (pre-treatment baseline, CHR and CHR + ACU) ANOVA. In all cases, significant effects were further explored using simple contrasts. All data analyses were performed using the SPSS (version 22; SPSS, Chicago, IL) statistical package, with statistical significance accepted at $P<0.05$. Results are presented as mean \pm SD unless stated otherwise.

\section{RESULTS}

Self-reported compliance to the supplementation regime was $100 \%$ in all treatment groups. Subjects reported that their diet and exercise habits prior to each experimental test were consistent. 


\subsection{Plasma $\left[\mathrm{NO}_{3}^{-}\right]$and $\left[\mathrm{NO}_{2}^{-}\right]$}

Plasma $\left[\mathrm{NO}_{3}^{-}\right]$and $\left[\mathrm{NO}_{2}^{-}\right]$responses in PLA, $3 \mathrm{mmol}$ and $6 \mathrm{mmol}$ groups are presented in Figures 2 and 3.

\subsection{1. $2 \mathrm{~h}, 7 \mathrm{~d}$ and $28-30$ day $(C H R+A C U)$}

At pre-treatment baseline, plasma $\left[\mathrm{NO}_{3}^{-}\right]$was not significantly different between treatment groups (PLA: $33 \pm 11 \mu \mathrm{M} ; 3$ mmol: $46 \pm 24 \mu \mathrm{M} ; 6$ mmol: $36 \pm 11 \mu \mathrm{M}: P>0.05$ ). The change in plasma $\left[\mathrm{NO}_{3}^{-}\right]$from pre-treatment baseline at $2 \mathrm{~h}, 7 \mathrm{~d}$ and on the $\mathrm{CHR}+\mathrm{ACU}$ visit after 28$30 \mathrm{~d}$ is shown in Fig. 2A. Plasma $\left[\mathrm{NO}_{3}^{-}\right]$was significantly elevated above pre-treatment baseline and PLA at all time points in the $3 \mathrm{mmol}$ and $6 \mathrm{mmol}$ groups (all $P<0.05$; Fig. 2A). The elevation in plasma $\left[\mathrm{NO}_{3}{ }^{-}\right]$above pre-treatment baseline in the $6 \mathrm{mmol}$ group was greater than in the $3 \mathrm{mmol}$ group at all time points (all $P<0.05$; Fig. 2A). The mean increase in plasma $\left[\mathrm{NO}_{3}{ }^{-}\right]$from pre-treatment baseline, in the $3 \mathrm{mmol}$ and $6 \mathrm{mmol}$ groups across the three sample points was $313 \%$ and $867 \%$, respectively ( $3 \mathrm{mmol}: 144 \pm 23 \mu \mathrm{M} ; 6 \mathrm{mmol}: 312 \pm 68 \mu \mathrm{M}$; both $P<0.05$; Fig. 2A). No changes in plasma $\left[\mathrm{NO}_{3}{ }^{-}\right]$were observed in the PLA group at any time point (all $P>0.05$ ). The rise in plasma $\left[\mathrm{NO}_{3}{ }^{-}\right]$from pre-treatment baseline was not significantly different between the three sampling time points within any treatment group (all $P>0.05$ ).

At pre-treatment baseline, plasma $\left[\mathrm{NO}_{2}^{-}\right]$was not significantly different between treatment groups (PLA: $43 \pm 19 \mathrm{nM} ; 3$ mmol: $80 \pm 69 \mathrm{nM} ; 6 \mathrm{mmol}: 48 \pm 22 \mathrm{nM}: P>0.05)$. The change in plasma $\left[\mathrm{NO}_{2}^{-}\right]$from pre-treatment baseline at $2 \mathrm{~h}, 7 \mathrm{~d}$ and on the $\mathrm{CHR}+\mathrm{ACU}$ after $28-30 \mathrm{~d}$ is shown in Fig. 2B. In the $3 \mathrm{mmol}$ and $6 \mathrm{mmol}$ groups, plasma $\left[\mathrm{NO}_{2}^{-}\right]$was significantly elevated at all time points (all $P<0.05$; Fig. 2B), relative to pre-treatment baseline and PLA. In addition, the rise in plasma $\left[\mathrm{NO}_{2}^{-}\right]$was greater in the $6 \mathrm{mmol}$ group than in the $3 \mathrm{mmol}$ group 
at all time points (all $P<0.05$; Fig. $2 \mathrm{~B}$ ). Across the three sample points, plasma $\left[\mathrm{NO}_{2}^{-}\right]$rose by $165 \%$ and $579 \%$, above pre-treatment baseline, in the $3 \mathrm{mmol}(132 \pm 49 \mathrm{nM})$ and $6 \mathrm{mmol}(278$ $\pm 155 \mathrm{nM}$; all $P<0.05$; Fig. $2 \mathrm{~B})$ groups, respectively. No changes in plasma $\left[\mathrm{NO}_{2}^{-}\right]$were observed in the PLA group at any time point (all $P>0.05$ ). The rise in plasma $\left[\mathrm{NO}_{2}^{-}\right]$from pre-treatment baseline was not significantly different between the three sampling time points within any treatment group (all $P>0.05$ ).

\subsubsection{Comparison between chronic and chronic + acute supplementation}

The change in plasma $\left[\mathrm{NO}_{3}{ }^{-}\right]$from pre-treatment baseline was significantly lower on the $\mathrm{CHR}$ visit compared to the $\mathrm{CHR}+\mathrm{ACU}$ visit in both the $3 \mathrm{mmol}$ and $6 \mathrm{mmol}$ groups $(P<0.05$; Fig. $3 \mathrm{~A})$. In the $3 \mathrm{mmol}$ group, plasma $\left[\mathrm{NO}_{3}^{-}\right]$had returned to pre-treatment baseline on the $\mathrm{CHR}$ $\operatorname{visit}\left(P>0.05\right.$; Fig. 3A). In the 6 mmol group, the plasma $\left[\mathrm{NO}_{3}{ }^{-}\right]$remained elevated above pretreatment baseline by $34 \pm 36 \mu \mathrm{M}(P<0.05$; Fig. $3 \mathrm{~A})$ on the CHR visit.

The change in plasma $\left[\mathrm{NO}_{2}^{-}\right]$from pre-treatment baseline was significantly lower on the CHR visit compared to $\mathrm{CHR}+\mathrm{ACU}$ visit in the $3 \mathrm{mmol}$ and $6 \mathrm{mmol}$ groups $(P<0.05$; Fig. $3 \mathrm{~B})$. Plasma $\left[\mathrm{NO}_{2}^{-}\right]$had returned to pre-treatment baseline on the CHR visit in both the $3 \mathrm{mmol}$ and $6 \mathrm{mmol}$ groups $(P>0.05$; Fig. 3B)

\subsection{Moderate-Intensity Exercise}

At pre-treatment baseline, the $\dot{V} o_{2}$ measured over the final 60 -s of moderate intensity exercise was not significantly different between treatment groups (PLA: $1.46 \pm 0.32 \mathrm{~L} \cdot \mathrm{min}^{-1} ; 3 \mathrm{mmol}$ : $\left.1.44 \pm 0.23 \mathrm{~L} \cdot \mathrm{min}^{-1} ; 6 \mathrm{mmol}: 1.44 \pm 0.30 \mathrm{~L} \cdot \mathrm{min}^{-1}: P>0.05\right)$.

\subsection{1. $2 \mathrm{~h}, 7 \mathrm{~d}$ and $28-30$ day $(C H R+A C U)$}


The change in end-exercise $\dot{V}_{O_{2}}$ from pre-treatment baseline at $2 \mathrm{~h}, 7 \mathrm{~d}$ and on the $\mathrm{CHR}+\mathrm{ACU}$ visit after 28-30 d is shown in Fig. 4A. In the $3 \mathrm{mmol}$ and PLA groups, end-exercise $\dot{V}_{O_{2}}$ was not significantly different from pre-treatment baseline at any time point (all $P>0.05$; Fig. 4A). Compared to pre-treatment baseline, end-exercise $\dot{V} O_{2}$ was significantly reduced in the 6 mmol $\mathrm{NO}_{3}{ }^{-}$group at $7 \mathrm{~d}\left(\right.$ by $\left.\sim 3 \% ; 0.04 \pm 0.05 \mathrm{~L} \cdot \mathrm{min}^{-1}\right)$ and $28-30 \mathrm{~d}$ on the $\mathrm{CHR}+\mathrm{ACU}$ visit (by $\sim 3 \% ; 0.04 \pm 0.04 \mathrm{~L} \cdot \mathrm{min}^{-1}$; both $P<0.05$; Fig. 4A), and tended to be reduced at $2 \mathrm{~h}$ (by $\sim 3 \%$; $0.04 \pm 0.02 \mathrm{~L} \cdot \mathrm{min}^{-1} ; P=0.06$; Fig. 4A). Compared to PLA, end-exercise $\dot{V}_{O_{2}}$ was significantly reduced in the $6 \mathrm{mmol}$ group at $28-30 \mathrm{~d}$ on the $\mathrm{CHR}+\mathrm{ACU}$ visit $(P<0.05$; Fig. 4A) and tended to be reduced at $7 \mathrm{~d}(P=0.08$; Fig. 4A). Compared to pre-treatment baseline and PLA, baseline, end-exercise and change in blood [lactate] were not altered by $3 \mathrm{mmol}$ or $6 \mathrm{mmol}$ $\mathrm{NO}_{3}{ }^{-}$at $2 \mathrm{~h}, 7 \mathrm{~d}$ or $28-30 \mathrm{~d}$ on the $\mathrm{CHR}+\mathrm{ACU}$ visit $(P>0.05)$.

\subsubsection{Comparison between chronic and chronic + acute supplementation}

In the $3 \mathrm{mmol}$ group, end-exercise $\dot{V}_{O_{2}}$ was not different from pre-treatment baseline at 28-30 $\mathrm{d}$ on either the CHR or CHR $+\mathrm{ACU}$ visits $(P>0.05)$. In the $6 \mathrm{mmol}$ group, end-exercise $\mathrm{V}_{2}$ was significantly lower than pre-treatment baseline at 28-30 days on the CHR visit (by $\sim 3.5 \%$; $0.05 \pm 0.06 \mathrm{~L} \cdot \mathrm{min}^{-1} ; P<0.05 ;$ Fig. 4B). This reduction in end-exercise $\dot{V} O_{2}$ was not significantly different from that observed on the CHR + ACU visit ( $P>0.05$; Fig. 4B).

\section{DISCUSSION}

The principal novel finding of the present study was that neither 7 days nor $\sim 4$ weeks of supplementation with $3 \mathrm{mmol} \mathrm{NO}_{3}{ }^{-}$, per day, reduced the $\mathrm{O}_{2}$ cost of moderate-intensity cycle exercise, despite an increase in plasma $\left[\mathrm{NO}_{3}{ }^{-}\right]$and $\left[\mathrm{NO}_{2}^{-}\right]$throughout the supplementation period. In contrast, the greater rise in plasma $\left[\mathrm{NO}_{3}^{-}\right]$and $\left[\mathrm{NO}_{2}^{-}\right]$with $6 \mathrm{mmol} \mathrm{NO}_{3}^{-}$was associated with a significant reduction in the $\mathrm{O}_{2}$ cost of moderate-intensity cycle exercise after 
7 days and $\sim 4$ weeks of supplementation, and a trend $(P=0.06)$ for a reduction after acute (2 h) ingestion. Interestingly, this reduction in moderate-intensity $\dot{V} o_{2}$ after $\sim 4$ weeks of supplementation was still evident when assessed on a separate occasion without the ingestion of $\mathrm{NO}_{3}{ }^{-} 2 \mathrm{~h}$ prior to the exercise test and thus, no elevation in plasma $\left[\mathrm{NO}_{2}{ }^{-}\right]$. This study is the first to demonstrate a lowering of submaximal $\dot{V} o_{2}$ following chronic $\mathrm{NO}_{3}{ }^{-}$supplementation without a significant concomitant increase in systemic $\left[\mathrm{NO}_{2}^{-}\right]$.

\subsection{The influence of $2 \mathrm{~h}, 7 \mathrm{~d}$ and 28-30 d (Chronic + Acute) $\mathrm{NO}_{3}{ }^{-}$supplementation}

\subsubsection{Plasma $\left[\mathrm{NO}_{3}^{-}\right]$and $\left[\mathrm{NO}_{2}^{-}\right]$}

The administration of beetroot extract containing $3 \mathrm{mmol}$ and $6 \mathrm{mmol} \mathrm{NO}_{3}{ }^{-}$was successful in dose-dependently elevating plasma $\left[\mathrm{NO}_{3}{ }^{-}\right]$and $\left[\mathrm{NO}_{2}{ }^{-}\right]$, a finding consistent with that observed after the ingestion of concentrated $\mathrm{NO}_{3}{ }^{-}$-rich beetroot juice [6] and pharmaceutical $\mathrm{NO}_{3}{ }^{-}$salt [20]. In both the $3 \mathrm{mmol}$ and $6 \mathrm{mmol}$ groups, there was no further increase in plasma $\left[\mathrm{NO}_{3}{ }^{-}\right]$ or $\left[\mathrm{NO}_{2}^{-}\right]$after 7 days or 28-30 days supplementation (when an acute bolus of $\mathrm{NO}_{3}^{-}$was consumed $2 \mathrm{~h}$ prior to assessment), compared to the acute ingestion of a single bolus of $\mathrm{NO}_{3}{ }^{-}$ on day 1 . This finding is also in line with previous observations [9,21].

\subsection{2. $\mathrm{O}_{2}$ cost of submaximal exercise}

In the present study we found that the steady-state $\dot{V} o_{2}$ measured over the final $60 \mathrm{~s}$ of moderate-intensity cycle exercise was unaffected by the acute ingestion of $3 \mathrm{mmol} \mathrm{NO}_{3}{ }^{-}$but tended $(P=0.06)$ to be lower by $3 \%$ following acute ingestion of $6 \mathrm{mmol} \mathrm{NO}_{3}{ }^{-}$. Several previous studies have also reported a dose-response relationship, with higher but not lower doses of dietary $\mathrm{NO}_{3}{ }^{-}$eliciting physiological effects [6,22,23]. In particular, we have previously 
reported that the $\mathrm{O}_{2}$ cost of submaximal cycling was unaffected by the acute administration of $4.2 \mathrm{mmol} \mathrm{NO}_{3}{ }^{-}$, tended to be reduced (by $1.7 \%$ ) following administration of $8.4 \mathrm{mmol}_{3}{ }^{-}$,

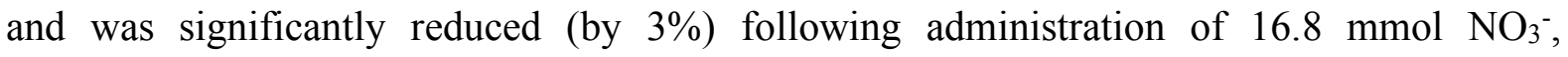
administered in the form of concentrated beetroot juice [6]. The reason for the greater relative reduction in submaximal exercise $\dot{V} o_{2}$ for a given $\mathrm{NO}_{3}{ }^{-}$dose in the present study (i.e. $3 \%$ reduction with $6 \mathrm{mmol} \mathrm{NO}_{3}{ }^{-}$) compared to that reported by us previously (i.e. $1.7 \%$ reduction with $8.4 \mathrm{mmol} \mathrm{NO}_{3}^{-}$) [6] is unclear. However, despite this, the results presented herein and by us previously [6] support a dose-dependent effect of acute $\mathrm{NO}_{3}{ }^{-}$ingestion on submaximal exercise $\dot{V} o_{2}$, and suggest that higher doses of $\mathrm{NO}_{3}{ }^{-}\left(\geq 6 \mathrm{mmol} \mathrm{NO}_{3}{ }^{-}\right)$are required to acutely lower the $\mathrm{O}_{2}$ cost of submaximal exercise.

This is the first study to investigate the effect of chronic supplementation with a low dose of $\mathrm{NO}_{3}{ }^{-}$on the $\mathrm{O}_{2}$ cost of moderate-intensity exercise. Contrary to our experimental hypothesis, we found that prolonging the supplementation period with $3 \mathrm{mmol} \mathrm{NO}_{3}{ }^{-}$to 7 days, and further to $\sim 4$ weeks, did not lower the $\mathrm{O}_{2}$ cost of submaximal cycle exercise. These results suggest that a reduction in submaximal exercise $\dot{V} o_{2}$ cannot be achieved with a low dose of $\mathrm{NO}_{3}{ }^{-}$even with an extension of the supplementation period. In contrast, we found that the $\mathrm{O}_{2}$ cost of submaximal exercise was significantly lower than pre-treatment baseline after both 7 days and $\sim 4$ weeks of supplementation with $6 \mathrm{mmol} \mathrm{NO}_{3}^{-}$. These findings are in agreement with the 3$6 \%$ reduction in the $\mathrm{O}_{2}$ cost of submaximal exercise reported in untrained subjects following 3-15 days of supplementation with 5-8 $\mathrm{mmol} \mathrm{NO}_{3}^{-}[4,5,9,12,24]$. Therefore, these results indicate that the daily ingestion of $6 \mathrm{mmol} \mathrm{NO}_{3}{ }^{-}$reduces the $\mathrm{O}_{2}$ cost of submaximal exercise after short duration ( 7 day) supplementation, and that this effect is maintained over $\sim 4$ weeks of continued supplementation with no evidence of a reduced sensitivity to supplementation. 
The lowering of submaximal exercise $\dot{V} \boldsymbol{o}_{2}$ may be a result of improved mitochondrial efficiency [12,25, cf. 26] and/or a reduction in the ATP cost of skeletal muscle force production [27]. Alterations in the expression, and therefore content, of mitochondrial [12] and contractile proteins [13] have been proposed as the mechanistic bases for these effects. However, alterations in protein expression are unlikely to occur within 1-3 h of acute $\mathrm{NO}_{3}{ }^{-}$ingestion, and can therefore only contribute to a reduction in submaximal exercise $\dot{V} \boldsymbol{o}_{2}$ after a period of chronic $\mathrm{NO}_{3}{ }^{-}$supplementation. Instead, a reduction in $\dot{V} o_{2}$ following acute $\mathrm{NO}_{3}{ }^{-}$ingestion may be related to an acute and reversible change in protein function through post-translational protein modifications [28]. Given the potential for the protein expression changes to occur after chronic supplementation but not acute ingestion, we hypothesized that the prolonged exposure to elevated concentrations of $\mathrm{NO}_{2}^{-}$provided by a chronic supplementation regime may reduce the dose of $\mathrm{NO}_{3}{ }^{-}$required to lower submaximal exercise $\dot{V} o_{2}$. In contrast to this hypothesis we found that extending the duration of supplementation on a low dose of $\mathrm{NO}_{3}{ }^{-}$to $\sim 4$ weeks did not result in a reduction in submaximal exercise $\dot{V} o_{2}$. This observation implies that these structural modifications are not only dependent on the duration of exposure but also the magnitude of the exposure. The influence of different $\mathrm{NO}_{3}{ }^{-}$doses and durations of supplementation on structural modifications to skeletal muscle warrants further investigation.

\subsection{The effect of chronic $\mathrm{NO}_{3}^{-}$supplementation in the absence of acute $\mathrm{NO}_{3}{ }^{-}$ingestion}

In all previous studies examining the effect of chronic $\mathrm{NO}_{3}^{-}$supplementation on the physiological responses to exercise, subjects have been instructed to consume their final dose of $\mathrm{NO}_{3}^{-} 1-3 \mathrm{~h}$ prior to testing [e.g. 4,5,9,12,27,29]. This experimental approach has been adopted to ensure a significant elevation in plasma $\left[\mathrm{NO}_{2}^{-}\right]$(and therefore the potential for $\mathrm{O}_{2}$ independent NO synthesis) at the time of assessment. However, considering that: 1) for a given dose, the rise in plasma $\left[\mathrm{NO}_{2}^{-}\right]$afforded by this chronic supplementation strategy is not 
different to that afforded by a single acute bolus of $\left.\mathrm{NO}_{3}^{-}[9,21] ; 2\right)$ acute $\mathrm{NO}_{3}^{-}$- supplementation may reduce submaximal exercise $\dot{V} o_{2}$ and improve exercise tolerance [6]; and 3) the acute effects of $\mathrm{NO}_{3}{ }^{-}$are believed to be mediated via an elevation in plasma $\left[\mathrm{NO}_{2}{ }^{-}\right][6,9]$; it is not possible to fully ascertain if the effects observed after chronic $\mathrm{NO}_{3}{ }^{-}$supplementation would still be evident when an acute $\mathrm{NO}_{3}{ }^{-}$dose is not administered. Therefore, in the present study, we examined the effects of chronic $\mathrm{NO}_{3}{ }^{-}$supplementation both with and without administration of an acute $\mathrm{NO}_{3}{ }^{-}$dose. Specifically, subjects were asked to consume their final dose of $\mathrm{NO}_{3}{ }^{-}$ $24 \mathrm{~h}$ prior to exercise testing. Importantly, $24 \mathrm{~h}$ provided sufficient time for plasma $\left[\mathrm{NO}_{2}{ }^{-}\right]$to return to pre-treatment baseline, a finding that is in agreement with the pharmacokinetics of plasma $\left[\mathrm{NO}_{2}^{-}\right]$following acute ingestion of similar $\mathrm{NO}_{3}^{-}$doses $[6,20]$.

An original finding of the present study was that moderate-intensity steady-state $\dot{V} \boldsymbol{o}_{2}$ was significantly lowered following $\sim 4$ weeks of supplementation with $6 \mathrm{mmol} \mathrm{NO}_{3}{ }^{-}$, even when $24 \mathrm{~h}$ had elapsed since the ingestion of the last $\mathrm{NO}_{3}{ }^{-}$dose. To our knowledge, these results are the first to demonstrate a reduction in submaximal exercise $\dot{V} o_{2}$ following $\mathrm{NO}_{3}^{-}$ supplementation in the absence of an increase in plasma $\left[\mathrm{NO}_{2}^{-}\right]$. However, this observation is consistent with a previous report that the physiological effects of $\mathrm{NO}_{3}{ }^{-}$supplementation can be achieved without an accompanying rise in plasma $\left[\mathrm{NO}_{2}^{-}\right][30]$. Specifically, Ferguson et al., [30] showed that despite no increase in plasma $\left[\mathrm{NO}_{2}{ }^{-}\right]$after 5 days of $\mathrm{NO}_{3}^{-}$supplementation in rats, microvascular $\mathrm{O}_{2}$ partial pressure was elevated during contraction in fast-twitch skeletal muscle. Interestingly, the magnitude of reduction in $\dot{V} o_{2}$ was not significantly different to that observed after $\sim 4$ weeks of supplementation when an acute bolus of $\mathrm{NO}_{3}{ }^{-}$was consumed prior to testing. These results therefore suggest that following chronic supplementation with $6 \mathrm{mmol}$ $\mathrm{NO}_{3}{ }^{-}$, a reduction in the $\mathrm{O}_{2}$ cost of submaximal exercise may be preserved up to at least $24 \mathrm{~h}$ after the final dose of $\mathrm{NO}_{3}{ }^{-}$is ingested, and that the addition of an acute $\mathrm{NO}_{3}{ }^{-}$dose, and the 
resulting elevation in plasma $\left[\mathrm{NO}_{2}^{-}\right]$, does not augment the reduction in submaximal exercise $\dot{V} \boldsymbol{o}_{2}$. The mechanistic basis for this preserved reduction in $\dot{V} \boldsymbol{o}_{2}$ is currently unclear. However, as briefly discussed earlier, the reduction in submaximal $\dot{V} o_{2}$ following chronic $\mathrm{NO}_{3}^{-}$ supplementation may be mediated, in part, by a change in the content of mitochondrial [12, cf 26] and contractile [13] proteins, and an associated improvement in mitochondrial [12, cf. 26] and contractile $[13,27]$ efficiency. It is likely that such structural adaptations are maintained for some period of time after $\mathrm{NO}_{3}{ }^{-}$supplementation is stopped, resulting in the preserved reduction in steady-state $\dot{V} o_{2}$. Indeed, the increased expression of mitochondrial proteins following sprint interval training have been observed up to 6 weeks after training was ceased [31].

Another possible explanation for the preserved reduction in steady-state $\dot{V} \boldsymbol{o}_{2}$ is that other reactive nitrogen intermediates and/or $\mathrm{NO}$ bioavailability remained elevated post $\mathrm{NO}_{3}^{-}$ supplementation, despite plasma $\left[\mathrm{NO}_{2}^{-}\right]$returning to pre-treatment baseline. Previous research in rodents has shown that skeletal muscle tissue acts as an endogenous $\mathrm{NO}_{2}{ }^{-}$and $\mathrm{NO}_{3}{ }^{-}$reservoir [32] and that $\mathrm{NO}_{2}{ }^{-}$infusion increases the concentration of $\mathrm{NO}_{2}{ }^{-}$in heart, liver and kidney tissue [33]. If this uptake is also true for human skeletal muscle following $\mathrm{NO}_{3}{ }^{-}$supplementation, it is possible that the pharmacokinetics of these changes are different to that of plasma $\left[\mathrm{NO}_{2}{ }^{-}\right]$ and $\left[\mathrm{NO}_{3}^{-}\right]$, and as a result, tissue $\mathrm{NO}_{2}^{-}$may accumulate and remain elevated beyond $24 \mathrm{~h}$ after the cessation of $\mathrm{NO}_{3}{ }^{-}$supplementation. An increase in tissue $\mathrm{NO}$ bioavailability may contribute to the reduction in $\dot{V} o_{2}$ via acutely and reversibly impacting mitochondrial and/or contractile protein function through post-translational protein modifications [28]. The preserved lowering of $\dot{V} o_{2}$ in the present study may therefore reflect a structural adaptation and/or elevated NO bioavailability in skeletal muscle tissue following 4 weeks of supplementation with 6 mmol 
$\mathrm{NO}_{3}{ }^{-}$. Further research is required to determine how long the reduction in submaximal exercise $\dot{V} o_{2}$ may be preserved following cessation of $\mathrm{NO}_{3}{ }^{-}$supplementation.

It should be noted that although the acute elevation of plasma $\left[\mathrm{NO}_{2}^{-}\right]$following chronic $\mathrm{NO}_{3}{ }^{-}$ supplementation did not augment the reduction in moderate-intensity $\dot{V} o_{2}$ in the present study, there are other potential benefits of the systemic rise in plasma $\left[\mathrm{NO}_{2}{ }^{-}\right]$resulting from the ingestion of an acute bolus of $\mathrm{NO}_{3}^{-}$. Recent evidence suggests that $\mathrm{NO}_{3}{ }^{-}$ingestion significantly improves the perfusion and oxygenation of skeletal muscle, particularly type II muscle fibers, during exercise [30,34]. The vascular effects of $\mathrm{NO}_{3}{ }^{-}$consumption are believed to be mediated acutely by $\mathrm{NO}_{2}{ }^{-}$or its reduction to the potent vasodilator $\mathrm{NO}[35,36]$. Indeed, an increase in blood flow to exercising forearm muscle has been reported following acute $\mathrm{NO}_{2}{ }^{-}$infusion [37]. Moreover, the acute increase in plasma $\left[\mathrm{NO}_{2}{ }^{-}\right]$following acute $\mathrm{NO}_{3}{ }^{-}$ingestion has been closely coupled to a reduction in blood pressure, with both returning back to pre-treatment baseline values simultaneously at $24 \mathrm{~h}[6,20]$. Collectively, these results suggest that improvements in perfusion and oxygenation following $\mathrm{NO}_{3}{ }^{-}$intake would not be preserved once $\mathrm{NO}_{3}{ }^{-}$ supplementation is ceased and plasma $\left[\mathrm{NO}_{2}^{-}\right]$returns back to baseline. If this is the case, an acute dose of dietary $\mathrm{NO}_{3}^{-}$following chronic supplementation may be beneficial before exercise in which improved oxygenation and perfusion in type II muscle fibers may be advantageous, i.e. high-intensity continuous and intermittent exercise. However, it must be acknowledged that a preserved improvement in vascular function could be possible if chronic $\mathrm{NO}_{3}{ }^{-}$supplementation results in a greater storage of tissue $\mathrm{NO}_{2}^{-}$(as discussed above) and this tissue $\mathrm{NO}_{2}{ }^{-}$is released into the circulation during exercise [32]. Therefore, further research is required to determine if any improvement in high-intensity exercise performance following chronic $\mathrm{NO}_{3}{ }^{-}$supplementation is preserved after supplementation is stopped and plasma $\left[\mathrm{NO}_{2}{ }^{-}\right.$ 
] returns to baseline. In the present study, we focused on the effects of $\mathrm{NO}_{3}{ }^{-}$on submaximal exercise $\dot{V} o_{2}$ and did not address possible changes in exercise performance.

In conclusion, low dose $(3 \mathrm{mmol}) \mathrm{NO}_{3}{ }^{-}$supplementation does not significantly reduce the $\mathrm{O}_{2}$ cost of submaximal cycle exercise acutely, or when the supplementation period is extended to $\sim 4$ weeks, despite a significant elevation in plasma $\left[\mathrm{NO}_{3}^{-}\right]$and $\left[\mathrm{NO}_{2}^{-}\right]$throughout the supplementation period. In contrast, the greater elevation in plasma $\left[\mathrm{NO}_{3}^{-}\right]$and $\left[\mathrm{NO}_{2}^{-}\right]$ following $6 \mathrm{mmol} \mathrm{NO}_{3}{ }^{-}$supplementation was accompanied by a reduction in the $\mathrm{O}_{2}$ cost of submaximal cycle exercise after $2 \mathrm{~h}(P=0.06), 7$ days and $\sim 4$ weeks (both $P<0.05$ ) of supplementation. The present study also demonstrated that the reduction in submaximal exercise $\dot{V} o_{2}$ after $\sim 4$ weeks supplementation with $6 \mathrm{mmol} \mathrm{NO}_{3}{ }^{-}$is preserved up to $24 \mathrm{~h}$ after the latest dose of $\mathrm{NO}_{3}{ }^{-}$is ingested and thus, in the absence of elevated plasma $\left[\mathrm{NO}_{2}^{-}\right]$. To our knowledge, this study is the first to dissociate the reduction in submaximal exercise $\dot{V} o_{2}$ from an increase in plasma $\left[\mathrm{NO}_{2}{ }^{-}\right]$following $\mathrm{NO}_{3}{ }^{-}$supplementation. This novel observation implies that beneficial structural skeletal muscle adaptations had occurred and were preserved, and/or muscle $\left[\mathrm{NO}_{2}^{-}\right]$remained elevated following chronic $\mathrm{NO}_{3}^{-}$supplementation.

\section{GRANTS}

Financial support for this study was provided by the Gatorade Sports Science Institute, a division of PepsiCo, Inc. The views expressed in this article are those of the authors and do not necessarily reflect the position or policy of PepsiCo, Inc.

\section{DISCLOSURES}

Coauthor Lara Nyman is an employee of the Gatorade Sports Science Institute, a division of PepsiCo, Inc. The views expressed in this article are those of the authors and do not necessarily reflect the position or policy of PepsiCo, Inc.

\section{REFERENCES}

[1] J.O. Lundberg, E. Weitzberg, NO generation from inorganic nitrate and nitrite: Role in physiology, nutrition and therapeutics, Arch. Pharm. Res. 32 (2009) 1119-1126. 
[2] J.O. Lundberg, M. Carlström, F.J. Larsen, E. Weitzberg, Roles of dietary inorganic nitrate in cardiovascular health and disease, Cardiovasc. Res. 89 (2010) 525-32

[3] S.J. Bailey, A. Vanhatalo, P.G. Winyard, A.M. Jones, The nitrate-nitrite-nitric oxide pathway: Its role in human exercise physiology, Eur. J. Sport Sci. 12 (2012) 309-320.

[4] F.J. Larsen, E. Weitzberg, J.O. Lundberg, B. Ekblom, Effects of dietary nitrate on oxygen cost during exercise, Acta Physiol. 191 (2007) 59-66.

[5] S.J. Bailey, P. Winyard, A. Vanhatalo, J.R. Blackwell, F.J. DiMenna, D.P. Wilkerson, et al., Dietary nitrate supplementation reduces the $\mathrm{O} 2$ cost of low-intensity exercise and enhances tolerance to high-intensity exercise in humans, J. Appl. Physiol. 107 (2009) 1144-1155.

[6] L.J. Wylie, J. Kelly, S.J. Bailey, J.R. Blackwell, P.F. Skiba, P.G. Winyard, et al., Beetroot juice and exercise: pharmacodynamic and dose-response relationships, J. Appl. Physiol. 115 (2013) 325-336.

[7] J. Kelly, A. Vanhatalo, D.P. Wilkerson, L.J. Wylie, A.M. Jones, Effects of nitrate on the power-duration relationship for severe-intensity exercise, Med Sci Sports Exerc. 45 (2013) 1798-1806.

[8] A.M. Jones, Dietary Nitrate Supplementation and Exercise Performance, Sports Med. Auckl. Nz. 44 (2014) 35-45. doi:10.1007/s40279-014-0149-y.

[9] A. Vanhatalo, S.J. Bailey, J.R. Blackwell, F.J. DiMenna, T.G. Pavey, D.P. Wilkerson, et al., Acute and chronic effects of dietary nitrate supplementation on blood pressure and the physiological responses to moderate-intensity and incremental exercise, Am. J. Physiol.-Regul. Integr. Comp. Physiol. 299 (2010) R1121-R1131.

[10] D.J. Muggeridge, C.C. Howe, O. Spendiff, C. Pedlar, P.E. James, C. Easton, et al., The effects of a single dose of concentrated beetroot juice on performance in trained flatwater kayakers, Int J Sport Nutr Exerc Metab. 23 (2013) 498-506.

[11] F.J. Larsen, E. Weitzberg, J.O. Lundberg, B. Ekblom, Dietary nitrate reduces maximal oxygen consumption while maintaining work performance in maximal exercise, Free Radic. Biol. Med. 48 (2010) 342-347.

[12] F.J. Larsen, T.A. Schiffer, S. Borniquel, K. Sahlin, B. Ekblom, J.O. Lundberg, et al., Dietary inorganic nitrate improves mitochondrial efficiency in humans, Cell Metab. 13 (2011) 149-159.

[13] A. Hernández, T.A. Schiffer, N. Ivarsson, A.J. Cheng, J.D. Bruton, J.O. Lundberg, et al., Dietary nitrate increases tetanic $[\mathrm{Ca} 2+] \mathrm{i}$ and contractile force in mouse fast-twitch muscle, J. Physiol. 590 (2012) 3575-3583.

[14] M. Govoni, E. \AA Jansson, E. Weitzberg, J.O. Lundberg, The increase in plasma nitrite after a dietary nitrate load is markedly attenuated by an antibacterial mouthwash, Nitric Oxide. 19 (2008) 333-337.

[15] W.L. Beaver, K. Wasserman, B.J. Whipp, A new method for detecting anaerobic threshold by gas exchange, J. Appl. Physiol. 60 (1986) 2020-2027.

[16] S.J. Bailey, D.P. Wilkerson, F.J. DiMenna, A.M. Jones, Influence of repeated sprint training on pulmonary $\mathrm{O} 2$ uptake and muscle deoxygenation kinetics in humans, $\mathrm{J}$. Appl. Physiol. 106 (2009) 1875-1887.

[17] B.J. Whipp, J.A. Davis, F. Torres, K. Wasserman, A test to determine parameters of aerobic function during exercise, J. Appl. Physiol. 50 (1981) 217-221.

[18] N. Lamarra, B.J. Whipp, S.A. Ward, K. Wasserman, Effect of interbreath fluctuations on characterizing exercise gas exchange kinetics, J. Appl. Physiol. 62 (1987) 20032012.

[19] P.E. James, G.R. Willis, J.D. Allen, P.G. Winyard, A.M. Jones, Nitrate pharmacokinetics: Taking note of the difference, Nitric Oxide. 48 (2015) 44-50. 
[20] V. Kapil, A.B. Milsom, M. Okorie, S. Maleki-Toyserkani, F. Akram, F. Rehman, et al., Inorganic nitrate supplementation lowers blood pressure in humans role for nitritederived NO, Hypertension. 56 (2010) 274-281.

[21] J. Fulford, P.G. Winyard, A. Vanhatalo, S.J. Bailey, J.R. Blackwell, A.M. Jones, Influence of dietary nitrate supplementation on human skeletal muscle metabolism and force production during maximum voluntary contractions, Pflüg. Arch. - Eur. J. Physiol. 465 (2013) 517-528. doi:10.1007/s00424-013-1220-5.

[22] S.K. Ferguson, D.M. Hirai, S.W. Copp, C.T. Holdsworth, J.D. Allen, A.M. Jones, et al., Dose dependent effects of nitrate supplementation on cardiovascular control and microvascular oxygenation dynamics in healthy rats, Nitric Oxide. 39 (2014) 51-58.

[23] M.W. Hoon, A.M. Jones, N.A. Johnson, J.R. Blackwell, E.M. Broad, B. Lundy, et al., The effect of variable doses of inorganic nitrate-rich beetroot juice on simulated 2,000m rowing performance in trained athletes, Int. J. Sports Physiol. Perform. 9 (2014) 615620. doi:10.1123/ijspp.2013-0207.

[24] K.E. Lansley, P.G. Winyard, J. Fulford, A. Vanhatalo, S.J. Bailey, J.R. Blackwell, et al., Dietary nitrate supplementation reduces the $\mathrm{O} 2$ cost of walking and running: a placebocontrolled study, J. Appl. Physiol. 110 (2011) 591-600.

[25] R.A. Vaughan, N.P. Gannon, C.R. Carriker, Nitrate-containing beetroot enhances myocyte metabolism and mitochondrial content, J. Tradit. Complement. Med. 6 (2015) 17-22. doi:10.1016/j.jtcme.2014.11.033.

[26] J. Whitfield, A. Ludzki, G.J.F. Heigenhauser, J.M.G. Senden, L.B. Verdijk, L.J.C. van Loon, et al., Beetroot juice supplementation reduces whole body oxygen consumption but does not improve indices of mitochondrial efficiency in human skeletal muscle, J. Physiol. 594 (2015) 421-35. doi:10.1113/JP270844.

[27] S.J. Bailey, J. Fulford, A. Vanhatalo, P.G. Winyard, J.R. Blackwell, F.J. DiMenna, et al., Dietary nitrate supplementation enhances muscle contractile efficiency during kneeextensor exercise in humans, J. Appl. Physiol. 109 (2010) 135-148.

[28] M.B. Reid, Role of nitric oxide in skeletal muscle: synthesis, distribution and functional importance, Acta Physiol. Scand. 162 (1998) 401-409.

[29] N.M. Cermak, M.J. Gibala, L.J. van Loon, others, Nitrate supplementation's improvement of 10-km time-trial performance in trained cyclists, Int. J. Sport Nutr. AndExercise Metab. 22 (2012) 64.

[30] S.K. Ferguson, C.T. Holdsworth, J.L. Wright, A.J. Fees, J.D. Allen, A.M. Jones, et al., Microvascular oxygen pressures in muscles comprised of different fiber types: impact of dietary nitrate supplementation, Nitric Oxide. 48 (2014) 38-43.

[31] K.A. Burgomaster, N.M. Cermak, S.M. Phillips, C.R. Benton, A. Bonen, M.J. Gibala, Divergent response of metabolite transport proteins in human skeletal muscle after sprint interval training and detraining, Am. J. Physiol. - Regul. Integr. Comp. Physiol. 292 (2007) R1970-R1976. doi:10.1152/ajpregu.00503.2006.

[32] B. Piknova, J.W. Park, K.M. Swanson, S. Dey, C.T. Noguchi, A.N. Schechter, Skeletal muscle as an endogenous nitrate reservoir, Nitric Oxide. 47 (2015) 10-16. doi:10.1016/j.niox.2015.02.145.

[33] N.S. Bryan, B.O. Fernandez, S.M. Bauer, M.F. Garcia-Saura, A.B. Milsom, T. Rassaf, et al., Nitrite is a signaling molecule and regulator of gene expression in mammalian tissues, Nat. Chem. Biol. 1 (2005) 290-297. doi:10.1038/nchembio734.

[34] S.K. Ferguson, D.M. Hirai, S.W. Copp, C.T. Holdsworth, J.D. Allen, A.M. Jones, et al., Impact of dietary nitrate supplementation via beetroot juice on exercising muscle vascular control in rats, J. Physiol. 591 (2013) 547-557. 
[35] L.J. Ignarro, G.M. Buga, K.S. Wood, R.E. Byrns, G. Chaudhuri, Endothelium-derived relaxing factor produced and released from artery and vein is nitric oxide., Proc. Natl. Acad. Sci. U. S. A. 84 (1987) 9265-9269.

[36] W.F. Alzawahra, M.A.H. Talukder, X. Liu, A. Samouilov, J.L. Zweier, Heme proteins mediate the conversion of nitrite to nitric oxide in the vascular wall, Am. J. Physiol. Heart Circ. Physiol. 295 (2008) H499-H508. doi:10.1152/ajpheart.00374.2008.

[37] K. Cosby, K.S. Partovi, J.H. Crawford, R.P. Patel, C.D. Reiter, S. Martyr, et al., Nitrite reduction to nitric oxide by deoxyhemoglobin vasodilates the human circulation, Nat. Med. 9 (2003) 1498-1505. doi:10.1038/nm954.

\section{Figure Legends}

Fig. 1. Schematic illustration of the study design. Following pre-treatment tests, all subjects were allocated to receive $6 \mathrm{mmol} \mathrm{NO}_{3}{ }^{-}, 3 \mathrm{mmol} \mathrm{NO}_{3}{ }^{-}$or placebo for $28-30$ days. All subjects completed two moderate-intensity bouts of cycle, $2 \mathrm{~h}$ post-ingestion (day 1; acute), and after 7, 28 and 30 days of supplementation. In the $3 \mathrm{mmol}$ and $6 \mathrm{mmol} \mathrm{NO}_{3}{ }^{-}$groups, subjects were randomised to receive a dose of placebo or $\mathrm{NO}_{3}^{-2} \mathrm{~h}$ prior to exercise testing in a counterbalanced order on days 28 and 30 of supplementation. This design enabled the efficacy of chronic $\mathrm{NO}_{3}{ }^{-}$supplementation in the absence and presence of an acute $\mathrm{NO}_{3}{ }^{-}$dose on the day of exercise testing to be determined. See main text for more details. 
Fig. 2. Change $(\Delta)$ relative to pre-treatment baseline in plasma $\left[\mathrm{NO}_{3}^{-}\right]$(panel $\left.\mathbf{A}\right)$ and $\left[\mathrm{NO}_{2}{ }^{-}\right]$ (panel B) following acute $(2 \mathrm{~h}), 7 \mathrm{~d}$ and 28-30 d (CHR + ACU) supplementation with 6 mmol $\mathrm{NO}_{3}{ }^{-}$(squares), $3 \mathrm{mmol} \mathrm{NO}_{3}^{-}$(triangles) and placebo (circles). Values are mean $\pm \mathrm{SE}$. * significant difference from pre-treatment baseline $(P<0.05)$; \# significant difference from placebo group $(P<0.05)$; $¥$ significant difference from placebo and $3 \mathrm{mmol} \mathrm{NO}^{-}$group $(P<$ $0.05)$

Fig. 3. Change $(\Delta)$ relative to pre-treatment baseline in plasma $\left[\mathrm{NO}_{3}{ }^{-}\right]$(panel A) and $\left[\mathrm{NO}_{2}{ }^{-}\right]$ (panel B) following 28 - $30 \mathrm{~d}$ supplementation with $6 \mathrm{mmol} \mathrm{NO}_{3}{ }^{-}$(squares) and $3 \mathrm{mmol} \mathrm{NO}_{3}{ }^{-}$ (triangles) when subjects consumed an acute dose of $\mathrm{NO}_{3}{ }^{-}(\mathrm{CHR}+\mathrm{ACU})$ or placebo $(\mathrm{CHR}) 2$ $\mathrm{h}$ prior to assessment. Values are mean $\pm \mathrm{SE}$. * significant difference from pre-treatment baseline $(P<0.05)$.

Fig. 4. The effect of $\mathrm{NO}_{3}{ }^{-}$supplementation on end-exercise $\dot{V} o_{2}$ during moderate-intensity cycle. Panel A: Change $(\Delta)$ relative to pre-treatment baseline in end-exercise $\dot{V} o_{2}$ following acute ( $2 \mathrm{~h}$ ), $7 \mathrm{~d}$ and 28-30 d (chronic + acute) supplementation with $6 \mathrm{mmol} \mathrm{NO}_{3}^{-}$(squares), 3 mmol $\mathrm{NO}_{3}{ }^{-}$(triangles) and placebo (circles). Panel B: Change $(\Delta)$ relative to pre-treatment baseline in end-exercise $\dot{V} o_{2}$ following 28 - 30-days supplementation with 6 mmol $\mathrm{NO}_{3}{ }^{-}$ (squares) and $3 \mathrm{mmol} \mathrm{NO}_{3}{ }^{-}$(triangles) when subjects consumed a dose of $\mathrm{NO}_{3}{ }^{-}(\mathrm{CHR}+A C U)$ or placebo $(C H R) 2 \mathrm{~h}$ prior to assessment. Values are mean \pm SE. $\dot{V} \boldsymbol{o}_{2}$, oxygen uptake. * Significant difference from pre-treatment baseline $(P<0.05)$; $₹$ trend towards difference from pre-treatment baseline $(P<0.10)$; \# significant difference from placebo group $(P<$ $0.05)$; $¥$ trend towards difference from placebo group $(P<0.10)$.

Table 1. Subject characteristics. Data expressed as mean \pm SD.

\begin{tabular}{lccc}
\hline & PLA & $3 \mathrm{mmol} \mathrm{NO}_{3}^{-}$ & $6 \mathrm{mmol} \mathrm{NO}_{3}^{-}$ \\
\hline & & & \\
$n$ & $11(7$ male $)$ & $11(6$ male $)$ & $12(6$ male $)$ \\
Age $(\mathrm{yr})$ & $21 \pm 4$ & $21 \pm 2$ & $22 \pm 3$ \\
Weight $(\mathrm{kg})$ & $75.9 \pm 20.4$ & $74.4 \pm 9.8$ & $70.5 \pm 10.4$ \\
Height $(\mathrm{m})$ & $1.74 \pm 0.11$ & $1.73 \pm 0.08$ & $1.75 \pm 0.09$ \\
\hline
\end{tabular}


Figure 1.

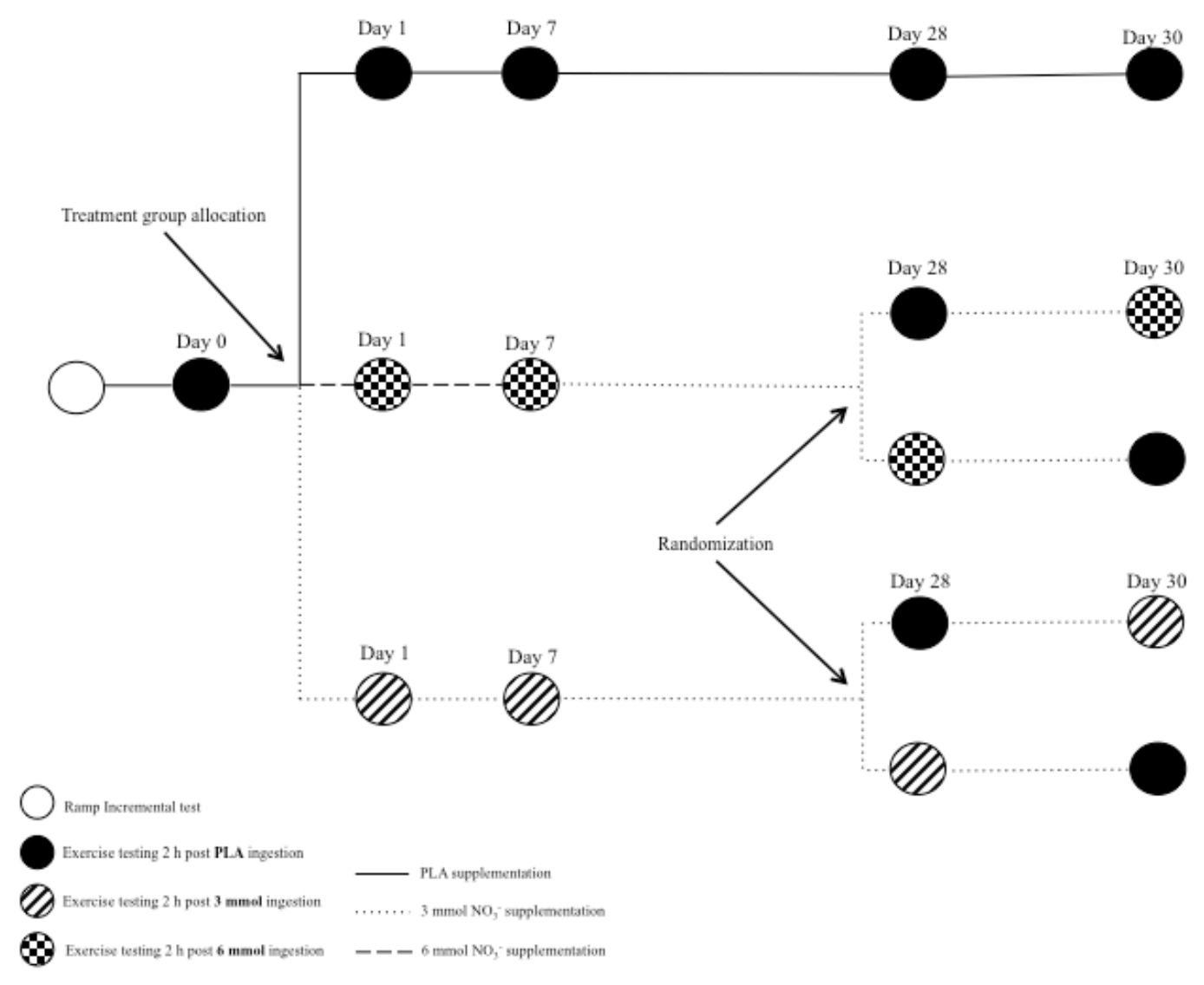


Figure 2.
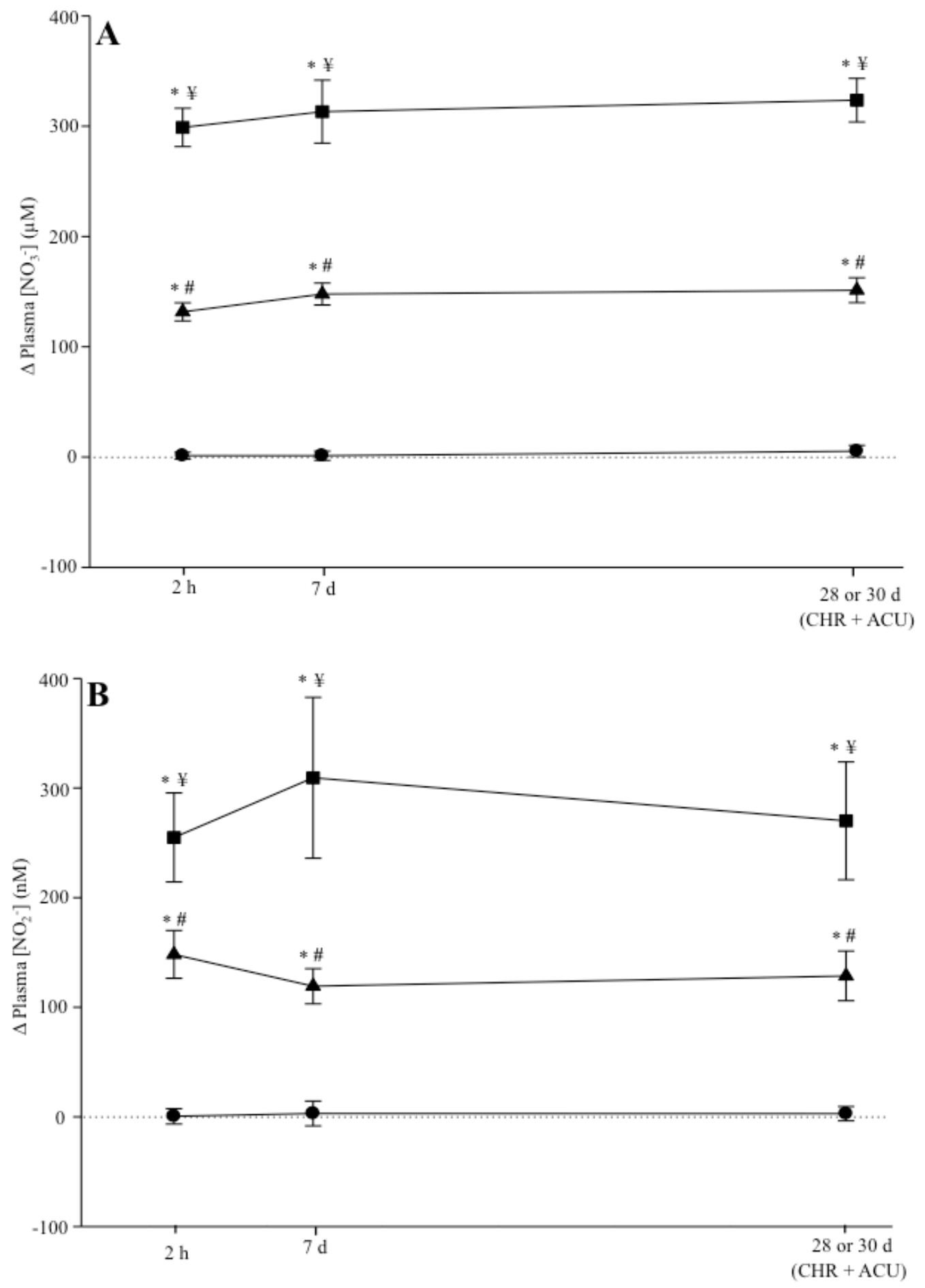
Figure 3
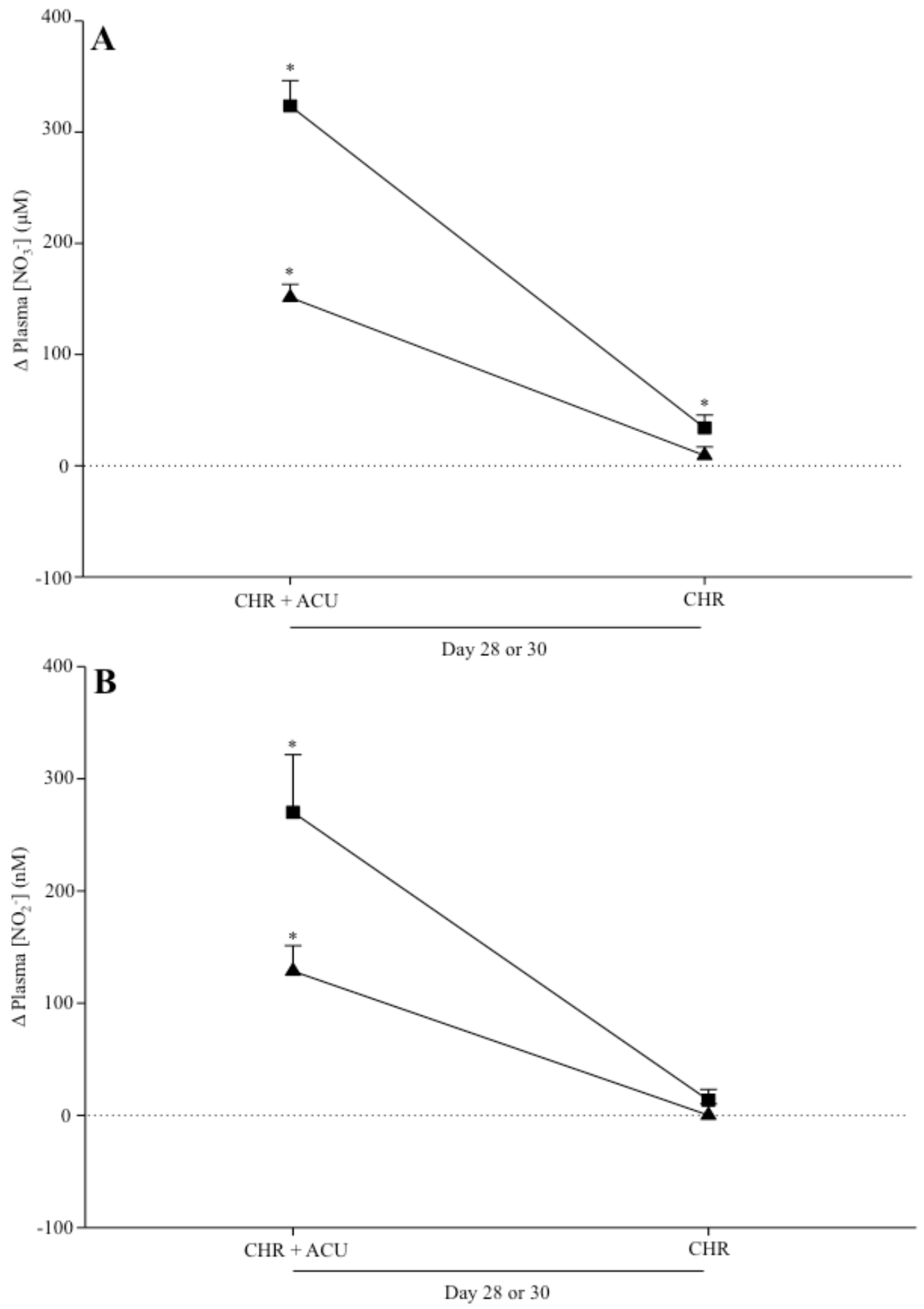
Figure 4.
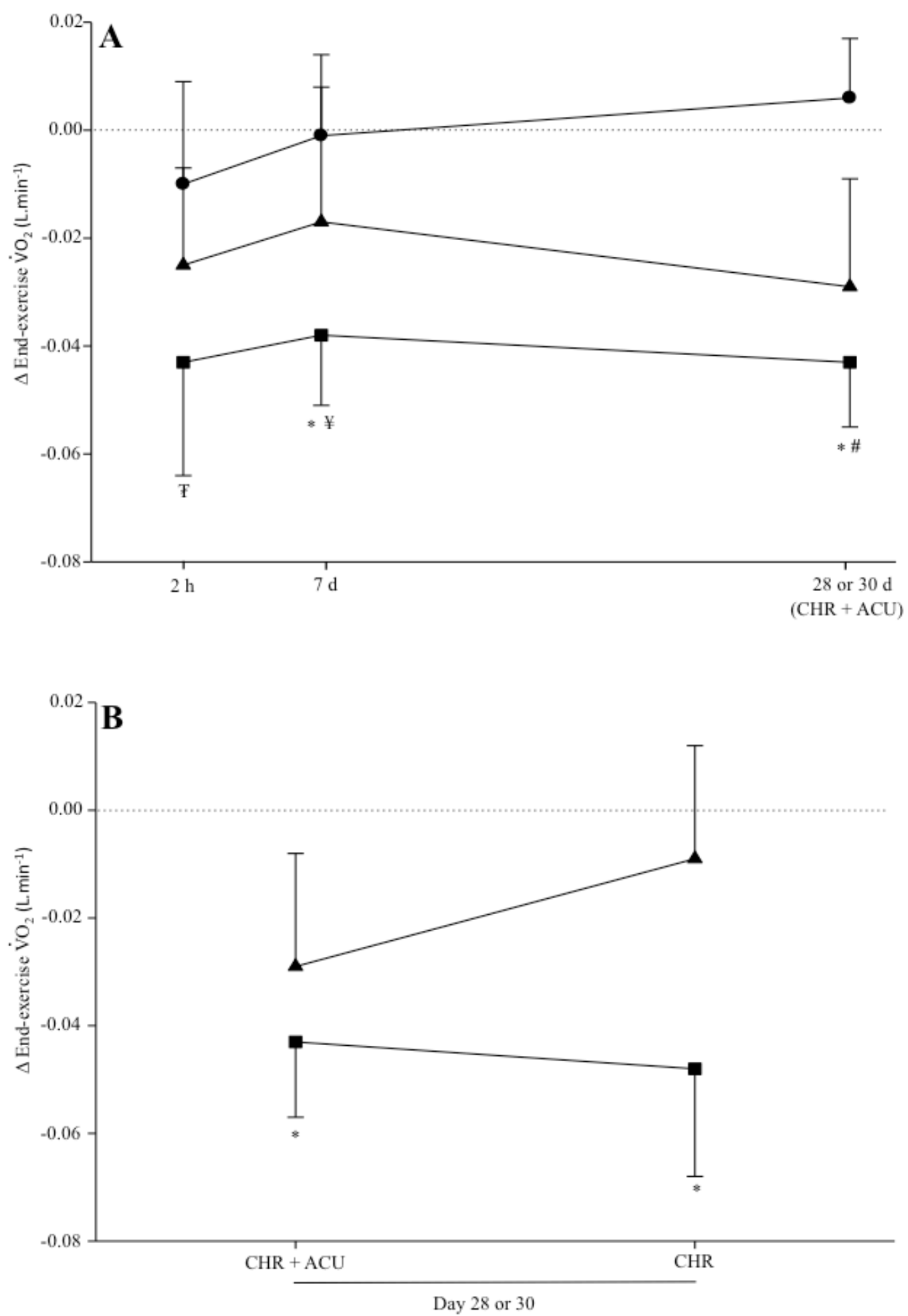
